\title{
Effect of Different Levels of Nitrogen and Methods of Application on Growth and Yield of Garlic (Allium sativum L.)
}

\author{
Piyush Verma, L. R. Varma, Yogesh Pawar* and P. C. Joshi
}

Department of Horticulture, C. P. College of Agriculture, S. D. Agricultural University, Sardarkrushinagar-385 506, Gujarat, India

*Corresponding author

\begin{tabular}{l} 
Ke y w o r d s \\
Garlic, Growth, \\
Nitrogen, Split \\
Application, Yield \\
\hline Article Info \\
\hline $\begin{array}{l}\text { Accepted: } \\
10 \text { April } 2020 \\
\text { Available Online: } \\
\text { 10 May } 2020\end{array}$ \\
\hline
\end{tabular}

A B S T R A C T

Field experiment was carried out from 2013- 14 to $2015-16$ at S. D. Agricultural University, Sardarkrushinagar to standardize the dose of nitrogen and its method of application in garlic under semi arid region of Gujarat. Twelve treatments comprising various combinations of nitrogen $(75,100,125,150,175$ and $200 \mathrm{~kg} \mathrm{~N} / \mathrm{ha})$ and methods of application (50\% $\mathrm{N}_{2}$ as a basal application \& $50 \%$ as in two split at 45 and 75 days of sowing and second level as $20 \% \mathrm{~N}_{2}$ as a basal application \& $80 \%$ as top dressing in four split at 30,50,70,90 days after sowing) were evaluated for growth and yield parameters of garlic. Growth and yield parameters were significantly improved by $125 \mathrm{~kg}$ nitrogen per hectare when applied through 20 per cent as basal and remaining 80 per cent as top dressing in four split at $30,50,70,90$ days after sowing.

\section{Introduction}

India ranks second in garlic production in world and among Indian states Gujarat ranks second in area and production with $35.0 \mathrm{~m}$ ha area and $250.0 \mathrm{~m} \mathrm{t}$ production. India is also a major exporter of garlic bulb, dehydrated garlic, garlic powder and garlic oil etc. Indian garlic is now exported even to Pakistan, Thailand and Malaysia, as well as the traditional market of Bangladesh.

Though the average productivity of garlic in state i.e. $7.14 \mathrm{t} / \mathrm{ha}$ is above national average i.e. $5.43 \mathrm{t} / \mathrm{ha}$. But still it is far behind the average yield of Punjab (12.16 t/ ha), West Bengal (11.94 t/ ha) and Maharashtra (11.43 t/ ha) (Anon, 2015). This yield gap might be due to several reasons viz. availability of improved cultivars, soil type, nutrition management, irrigation availability, plant protection measures etc. but among them nutrition plays an important role. The area of North Gujarat is characterized by semi arid and soil type is loamy sand. NPK requirement is different via state wise like Arunachal Pradesh-125:60:100, Assam-50:60:100, Goa10:70:100, Haryana-80:50:25. 
Till now the growers are following the ad-hoc recommendation of nutrition application of 100-50-50 NPK in which 50-50-50 NPK as basal and remaining $50 \mathrm{~kg}$ nitrogen in two equal splits at 30 and 50 days after planting but it was felt that as garlic is a long duration crop and soil type is sandy hence more splits of nitrogen can be more effective for yield. Further the dose should also be standardized which may be lower or higher then ad-hoc. In sandy soil, leaching rate of nitrogen is high as compare to clay type of soil. Fertilizer requirement of any crop varies with the soil condition and the soil of North Gujarat is sandy with poor organic Carbon and water holding capacity. In such situation application of Nitrogen to its maximum efficiency is a challenge.

Keeping this in view the present experiment was planned and executed to enhance the garlic productivity.

\section{Materials and Methods}

The experiment was carried out during rabi season for three consecutive years i.e. $2013-$ 14, 2014 - 15 and 2015 - 16 at Horticulture Instructional Farm, Department of Horticulture, C. P. College of Agriculture, S. D. Agricultural University, Sardarkrushinagar. The soil of experimental field was sandy loam textural class having $\mathrm{pH}$ and electrical conductivity 7.8 and $0.18 \mathrm{dSm}-1$ respectively. The fertility status of the experimental field was found to be low in organic carbon $(0.16 \%)$, low in organic carbon $(0.21 \%)$, medium in available phosphorus (37.11 kg ha-1) and available potash (287 kg ha-1). Except treatment application of nitrogen, all the cultural practices were uniformly followed to raise the crop. The cloves were planted at a spacing of $15 \mathrm{~cm} \mathrm{X} 7.5 \mathrm{~cm}$ in plot of $3.0 \mathrm{~m} \mathrm{X} 1.50 \mathrm{~m}$. Irrigation was applied through micro sprinklers.
The variety selected for the study was Agrifound White $(\mathrm{G}-41)$ was procured from NHRDF, Nasik during first year. Experiment was statistically laid out in Factorial Randomized Block Design which consisted of two factors viz. Nitrogen with six levels (75, $100,125,150,175$ and $200 \mathrm{~kg} \mathrm{~N} / \mathrm{ha})$ and methods of application with two levels (50\% $\mathrm{N}_{2}$ as a basal application \& $50 \%$ as in two split at 45 and 75 days of sowing and second level as $20 \% \mathrm{~N}_{2}$ as a basal application \& $80 \%$ as top dressing in four split at 30,50,70,90 days after sowing), thus making total 12 treatment combinations. Experiment was replicated thrice.

Treatments were evaluated for growth (Plant height $(\mathrm{cm})$ at 90 Days after planting, Number of leaves per plant, Days taken for bulb maturity, Neck thickness $(\mathrm{cm})$ at harvesting) and yield and yield attributes (Diameter of bulb $(\mathrm{cm})$, Weight of bulb (g), Number of cloves per bulb and Yield kg/plotand $\mathrm{q} / \mathrm{ha}$ ).

Plant height was measured with measuring scale while leaves numbers, days taken for bulb maturity from planting to harvesting were counted. Neck thickness and diameter of bulb was measured with digital verniarcalliper (CD-6" CSX, Mitutoya). Yield per plot was weighed after harvesting and curing which was converted in to per hectare basis. Weight of bulb was taken on digital balance. Number of cloves per bulb was also counted to record the data.

Ten plants from each net plot were tagged to record the data. The recorded data were subjected to statistical analysis using the analysis of variance technique (Gomez and Gomez, 1984).

\section{Results and Discussion}

\section{Effect of nitrogen}

Data present in tables revealed that growth, 
yield and quality of garlic cultivar Agrifound White was significantly influenced by dose of nitrogen. Perusal of table showed that plant height at 90 days after planting was significantly maximum by application of 125 $\mathrm{kg}$ nitrogen per hectare on pooled data basis. Though it was non-significantly differed with $100,150,175$ and $200 \mathrm{~kg} \mathrm{~N} / \mathrm{ha}$ application. On pooled data basis maximum number of leaves per plant of 8.14 was recorded under treatment $150 \mathrm{~kg} / \mathrm{ha}$ which was nonsignificant followed by 125,175 and $200 \mathrm{~kg}$ $\mathrm{N} / \mathrm{ha}$ treatment. Nitrogen increased the rates of leaf initiation and extension of garlic in early growth (Koltunov, 1984). This might be because of nitrogen is being an essential constituent of chlorophyll, protoplasm and enzymes and as it governs utilization of $\mathrm{P}$ and K. Similar results were also obtained by Yadav et al., (2007) and Thakur (2011).

Pooled analysis of data indicate that significantly maximum neck thickness of 6.85 $\mathrm{cm}$ at harvesting was observed in $\mathrm{N}_{2}$ treatment i.e. $100 \mathrm{~kg} \mathrm{~N} / \mathrm{ha}$ which was at par with 125,150 and $175 \mathrm{~kg} \mathrm{~N} / \mathrm{ha}$. Maximum diameter and weight of bulb $(3.44 \mathrm{~cm}$ and $24.15 \mathrm{~g}$, respectively) was recorded with application of $125 \mathrm{~kg} \mathrm{~N} / \mathrm{ha}$. Diameter of bulb was statistically at par in $\mathrm{N}_{2}, \mathrm{~N}_{4}, \mathrm{~N}_{5}$ and $\mathrm{N}_{6}$ treatments. Whereas, bulb weight in treatment $\mathrm{N}_{4}, \mathrm{~N}_{5}$ and $\mathrm{N}_{6}$.

Maximum number of cloves per bulb of 18.64 were recorded with treatment of $175 \mathrm{~kg} \mathrm{~N} / \mathrm{ha}$, though it was non-significantly followed by 125,150 and $200 \mathrm{~kg} \mathrm{~N} / \mathrm{ha}$ treatment.

Significantly maximum yield of $4.35 \mathrm{~kg}$ per plot and $124.05 \mathrm{q} / \mathrm{ha}$ was recorded with application of $125 \mathrm{~kg} \mathrm{~N} / \mathrm{ha}$ and though yield (Per plot and per hectare) was nonsignificantly differed with application of 150 $\mathrm{kg} \mathrm{N} / \mathrm{ha}$. This might be due to more availability of nitrogen to plant frequent application of nitrogen. Results of Reddy et al., (2000) and Yadav (2003) are in accordance with above results.

Pooled analysis of data indicate that significantly maximum neck thickness of 6.85 $\mathrm{cm}$ at harvesting was observed in $\mathrm{N}_{2}$ treatment i.e. $100 \mathrm{~kg} \mathrm{~N} / \mathrm{ha}$ which was at par with 125 , 150 and $175 \mathrm{~kg} \mathrm{~N} / \mathrm{ha}$. Maximum diameter and weight of bulb $(3.44 \mathrm{~cm}$ and $24.15 \mathrm{~g}$, respectively) was recorded with the application of $125 \mathrm{~kg} \mathrm{~N} / \mathrm{ha}$.

Diameter was statistically at par in $\mathrm{N}_{2}, \mathrm{~N}_{4}, \mathrm{~N}_{5}$ and $\mathrm{N}_{6}$ treatments whereas bulb weight in $\mathrm{N}_{4}$, $\mathrm{N}_{5}$ and $\mathrm{N}_{6}$. These findings were also reported by Panchal (1989) and Patel (1993). Cassman et al., (2002) Imbalanced and poorly monitored nitrogen application limits yields and induces large losses of reactive nitrogen to the environment.

\section{Effect of method of application}

Perusal of data clearly shows that method of application of nitrogen could not brought significant effect on various growth, yield and quality attributes of garlic except days taken for bulb maturity. Application of nitrogen as $20 \%$ basal and remaining of $80 \%$ as top dressing in four splits was able to reduce the crop period by about 4 days which was significantly superior over $50 \%$ nitrogen as basal and remaining $50 \%$ as two split.

\section{Interaction effect}

None of the interaction could statistically significantly influence the any of the parameter except plant height and neck thickness.

\section{Economics}

While comparing the cost involved and profit evolved i.e. economics of the experiment it was found that treatment $\mathrm{N}_{3}$ i.e. $125 \mathrm{~kg} / \mathrm{ha}$ 
Nitrogen was most profitable and economic in which Net income, additional income and ICBR of Rs. 3,70,449, Rs. 86,469 and 50.83, respectively was obtained. While out of two method of applications, treatment $\mathrm{M}_{2}$ (20\%Nitrogen as basal and remaining $80 \%$ in 4 equal splits at 30,50,70,90 DAS) recorded Net Income, Additional Income and ICBR of Rs. 3,22,155, Rs. 10,440 and 27.84, respectively.Variation in these profit values was due to yield obtained from different treatments which was accountable for maximum returns and benefit from different treatments.

Growth and yield parameters were significantly improved by $125 \mathrm{~kg}$ nitrogen per hectare when applied through 20 per cent as basal and remaining 80 per cent as top dressing in four split at 30,50,70,90 days after sowing.

Table.1

\begin{tabular}{|c|c|}
\hline $\begin{array}{l}\text { Treatment } \\
\text { no. }\end{array}$ & Treatment details \\
\hline $\mathbf{T}_{1}$ & $\begin{array}{l}75 \mathrm{~kg} \mathrm{~N} / \text { ha applied by } 50 \% \mathrm{~N} 2 \text { as a basal application \& } 50 \% \text { as in two split at } \\
45 \text { and } 75 \text { days of sowing }\end{array}$ \\
\hline $\mathbf{T}_{2}$ & $\begin{array}{l}75 \mathrm{~kg} \mathrm{~N} / \text { ha applied by } 20 \% \mathrm{~N} 2 \text { as a basal application \& } 80 \% \text { as top dressing in } \\
\text { four split at 30,50,70,90 days after sowing }\end{array}$ \\
\hline $\mathbf{T}_{\mathbf{3}}$ & $\begin{array}{l}100 \mathrm{~kg} \mathrm{~N} / \mathrm{ha} \text { applied by } 50 \% \mathrm{~N} 2 \text { as a basal application \& } 50 \% \text { as in two split at } \\
45 \text { and } 75 \text { days of sowing }\end{array}$ \\
\hline $\mathbf{T}_{4}$ & $\begin{array}{l}100 \mathrm{~kg} \mathrm{~N} / \mathrm{ha} \text { applied by } 20 \% \mathrm{~N} 2 \text { as a basal application \& } 80 \% \text { as top dressing } \\
\text { in four split at } 30,50,70,90 \text { days after sowing }\end{array}$ \\
\hline $\mathbf{T}_{5}$ & $\begin{array}{l}125 \mathrm{~kg} \mathrm{~N} / \text { ha applied by } 50 \% \mathrm{~N} 2 \text { as a basal application \& } 50 \% \text { as in two split at } \\
45 \text { and } 75 \text { days of sowing }\end{array}$ \\
\hline $\mathbf{T}_{6}$ & $\begin{array}{l}125 \mathrm{~kg} \mathrm{~N} / \mathrm{ha} \text { applied by } 20 \% \mathrm{~N} 2 \text { as a basal application \& } 80 \% \text { as top dressing } \\
\text { in four split at 30,50,70,90 days after sowing }\end{array}$ \\
\hline $\mathbf{T}_{7}$ & $\begin{array}{l}150 \mathrm{~kg} \mathrm{~N} / \text { ha applied by } 50 \% \mathrm{~N} 2 \text { as a basal application \& } 50 \% \text { as in two split at } \\
45 \text { and } 75 \text { days of sowing }\end{array}$ \\
\hline $\mathbf{T}_{8}$ & $\begin{array}{l}150 \mathrm{~kg} \mathrm{~N} / \mathrm{ha} \text { applied by } 20 \% \mathrm{~N} 2 \text { as a basal application \& } 80 \% \text { as top dressing } \\
\text { in four split at 30,50,70,90 days after sowing }\end{array}$ \\
\hline $\mathbf{T}_{9}$ & $\begin{array}{l}175 \mathrm{~kg} \mathrm{~N} / \text { ha applied by } 50 \% \mathrm{~N} 2 \text { as a basal application \& } 50 \% \text { as in two split at } \\
45 \text { and } 75 \text { days of sowing }\end{array}$ \\
\hline $\mathbf{T}_{10}$ & $\begin{array}{l}175 \mathrm{~kg} \mathrm{~N} / \mathrm{ha} \text { applied by } 20 \% \mathrm{~N} 2 \text { as a basal application \& } 80 \% \text { as top dressing } \\
\text { in four split at 30,50,70,90 days after sowing }\end{array}$ \\
\hline $\mathbf{T}_{11}$ & $\begin{array}{l}200 \mathrm{~kg} \mathrm{~N} / \text { ha applied by } 50 \% \mathrm{~N} 2 \text { as a basal application \& } 50 \% \text { as in two split at } \\
45 \text { and } 75 \text { days of sowing }\end{array}$ \\
\hline $\mathbf{T}_{12}$ & $\begin{array}{l}200 \mathrm{~kg} \mathrm{~N} / \mathrm{ha} \text { applied by } 20 \% \mathrm{~N} 2 \text { as a basal application \& } 80 \% \text { as top dressing } \\
\text { in four split at 30,50,70,90 days after sowing }\end{array}$ \\
\hline
\end{tabular}


Table.1 Main effect of nitrogen levels and methods of application on growth and yield of garlic cv. Agrifound White

\begin{tabular}{|c|c|c|c|c|c|c|c|c|c|c|c|c|}
\hline & \multicolumn{4}{|c|}{$\begin{array}{l}\text { Plant height }(\mathrm{cm}) \text { at } 90 \text { Days after } \\
\text { planting }\end{array}$} & \multicolumn{4}{|c|}{ Number of leaves per plant } & \multicolumn{4}{|c|}{ Days taken for bulb maturity } \\
\hline & 2013 & 2014 & 2015 & POOLED & 2013 & 2014 & 2015 & POOLED & 2013 & 2014 & 2015 & POOLED \\
\hline \multicolumn{13}{|c|}{ Nitrogen levels (N) } \\
\hline $\mathbf{N}_{2}$ & 64.28 & 53.84 & 65.36 & 61.16 & 8.06 & 6.93 & 7.45 & 7.48 & 163.41 & 154.67 & 166.77 & 161.61 \\
\hline $\mathbf{N}_{3}$ & 65.62 & 58.92 & 67.86 & 64.13 & 8.81 & 7.27 & 7.63 & 7.90 & 156.51 & 154.67 & 159.53 & 156.90 \\
\hline $\mathbf{N}_{6}$ & 64.55 & 56.09 & 67.81 & 62.82 & 9.23 & 7.50 & 7.92 & 8.21 & 170.36 & 154.67 & 157.48 & 160.84 \\
\hline S.Em \pm & 1.90 & 1.38 & 1.78 & 1.24 & 0.42 & 0.20 & 0.22 & 0.16 & 3.05 & 0.12 & 4.82 & 1.86 \\
\hline C.D. at $5 \%$ & NS & 4.09 & NS & NS & 1.22 & NS & $\mathrm{NS}$ & 0.48 & 8.89 & NS & NS & NS \\
\hline \multicolumn{13}{|c|}{ Methods of application (M) } \\
\hline $\mathbf{M}_{1}$ & 65.91 & 54.18 & 67.38 & 62.49 & 8.30 & 7.15 & 7.87 & 7.77 & 168.29 & 155.00 & 162.76 & 162.02 \\
\hline S.Em \pm & 2.69 & 1.95 & 2.52 & 1.76 & 0.59 & 0.28 & 0.32 & 0.23 & 4.32 & 0.17 & 6.82 & 2.63 \\
\hline C.D. at $5 \%$ & NS & NS & 7.34 & 5.11 & NS & NS & NS & NS & NS & NS & NS & NS \\
\hline \multicolumn{13}{|l|}{$\mathbf{Y} \times \mathbf{T}$} \\
\hline S.Em \pm & & & & 2.23 & & & & 0.36 & & & & 3.49 \\
\hline C.D. at $5 \%$ & & & & NS & & & & NS & & & & NS \\
\hline C. V. \% & 7.29 & 6.15 & 6.71 & 4.96 & 11.81 & 6.96 & 7.29 & 5.17 & 4.55 & 0.19 & 7.33 & 2.85 \\
\hline
\end{tabular}


Table.2 Main effect of nitrogen levels and methods of application on growth and yieldof garlic cv. Agrifound White

\begin{tabular}{|c|c|c|c|c|c|c|c|c|c|c|c|c|}
\hline & \multicolumn{4}{|c|}{ Neck thickness $(\mathrm{cm})$ at harvesting } & \multicolumn{4}{|c|}{ Diameter of bulb (cm) } & \multicolumn{4}{|c|}{ Weight of bulb (g) } \\
\hline & 2013 & 2014 & 2015 & POOLED & 2013 & 2014 & 2015 & POOLED & 2013 & 2014 & 2015 & POOLED \\
\hline \multicolumn{13}{|c|}{ Nitrogen levels $(\mathbf{N})$} \\
\hline $\mathbf{N}_{1}$ & 7.02 & 5.27 & 5.27 & 5.85 & 3.44 & 3.00 & 3.05 & 3.16 & 22.87 & 17.57 & 17.63 & 19.36 \\
\hline $\mathbf{N}_{3}$ & 7.04 & 5.25 & 6.68 & 6.32 & 3.63 & 3.31 & 3.37 & 3.44 & 25.87 & 23.33 & 23.25 & 24.15 \\
\hline $\mathbf{N}_{4}$ & 7.46 & 6.02 & 6.51 & 6.66 & 3.47 & 3.17 & 3.27 & 3.30 & 28.75 & 21.80 & 21.88 & 24.14 \\
\hline S.Em \pm & 0.40 & 0.34 & 0.28 & 0.22 & 0.13 & 0.11 & 0.09 & 0.09 & 0.40 & 1.87 & 1.00 & 0.85 \\
\hline C.D. at $5 \%$ & NS & NS & 0.83 & 0.64 & NS & NS & NS & NS & 1.18 & NS & 2.92 & 2.49 \\
\hline \multicolumn{13}{|c|}{ Methods of application (M) } \\
\hline $\mathbf{M}_{1}$ & 6.88 & 5.65 & 6.59 & 6.37 & 3.45 & 3.04 & 3.15 & 3.21 & 27.01 & 19.42 & 19.45 & 21.96 \\
\hline $\mathbf{M}_{2}$ & 7.68 & 5.82 & 5.82 & 6.44 & 3.65 & 3.16 & 3.20 & 3.33 & 28.51 & 19.83 & 19.86 & 22.73 \\
\hline C.D. at $5 \%$ & 1.68 & NS & 1.18 & 0.91 & NS & NS & NS & NS & 1.67 & NS & NS & NS \\
\hline \multicolumn{13}{|l|}{$\mathbf{Y} \times \mathbf{T}$} \\
\hline S.Em \pm & & & & 0.44 & & & & 0.15 & & & & 1.46 \\
\hline C.D. at $5 \%$ & & & & NS & & & & NS & & & & NS \\
\hline C. V. \% & 13.76 & 14.67 & 11.28 & 8.44 & 9.11 & 9.37 & 7.55 & 7.13 & 3.59 & 23.39 & 12.52 & 9.40 \\
\hline
\end{tabular}


Table.3 Main effect of nitrogen levels and methods of application on growth and yield of garlic cv. Agrifound White

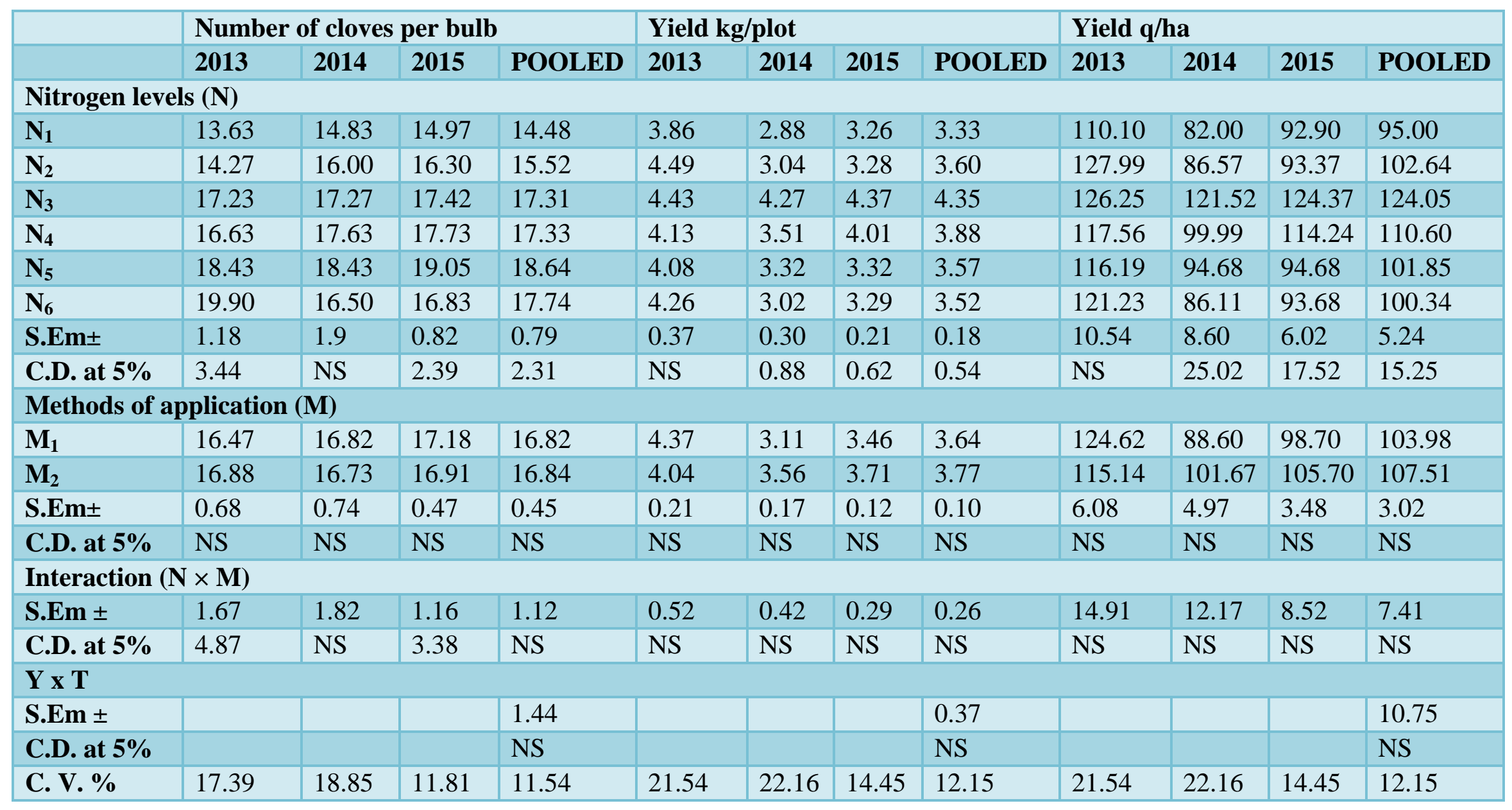


Table.4 Economics of the different treatments

\begin{tabular}{|c|c|c|c|c|c|c|}
\hline Treatment & $\begin{array}{l}\text { Pooled Yield } \\
\text { (q/ha) }\end{array}$ & $\begin{array}{c}\text { Gross Income } \\
\left(₹^{\prime}\right)\end{array}$ & $\begin{array}{c}\text { Treatment Cost } \\
\left(\sum^{\prime}\right)\end{array}$ & $\begin{array}{l}\text { Net Income } \\
\text { (₹) }\end{array}$ & $\begin{array}{c}\text { Additional Income } \\
\left(\gtrless^{\prime}\right)\end{array}$ & ICBR \\
\hline \multicolumn{7}{|c|}{ Nitrogen levels (N) } \\
\hline $\mathbf{N}_{1}$ & 95.00 & $2,85,000$ & 1,020 & $2,83,980$ & - & - \\
\hline $\mathbf{N}_{2}$ & 102.64 & $3,07,920$ & 1,361 & $3,06,559$ & 22579 & 16.59 \\
\hline $\mathbf{N}_{3}$ & 124.05 & $3,72,150$ & 1,701 & $3,70,449$ & 86469 & 50.83 \\
\hline $\mathbf{N}_{4}$ & 110.60 & $3,31,800$ & 2,041 & $3,29,759$ & 45779 & 22.43 \\
\hline $\mathbf{N}_{5}$ & 101.85 & $3,05,550$ & 2,381 & $3,03,169$ & 19189 & 8.06 \\
\hline $\mathbf{N}_{6}$ & 100.34 & $3,01,020$ & 2,722 & $2,98,298$ & 14318 & 5.17 \\
\hline \multicolumn{7}{|c|}{ Methods of application (M) } \\
\hline $\mathbf{M}_{1}$ & 103.98 & $3,11,940$ & 225 & $3,11,715$ & - & - \\
\hline$M_{2}$ & 107.51 & $3,22,530$ & 375 & $3,22,155$ & 10440 & 27.84 \\
\hline
\end{tabular}

Selling price $=$ Rs. 3000 per quintal

Labour cost $=$ Rs. 150 per man day

Price of urea $=$ Rs. 6.27 per $\mathrm{kg}$

\section{References}

Anon, 2015.NHRDF, State wise area, production and productivity data for garlic.www.nhrdf.com

Arekery, H. R., Chalam, G. V., Satyanarayan, P. and Donahue, R. L. 1956.Soil management in India, Asian Pub. House, Bombay.

Bhati, D. K., Singh, B. and Srivastava, D.K. 2002.Effect of levels of nitrogen and spacing on the yield and quality of garlic (Allium sativum L.). $J$. Progressive Agril. 2 (1): 75-78.

Cassman, K., Dobermann, A. and Walters, D. 2002. Agroecosystems, nitrogen use efficiency and nitrogen management. Ambio., 31(2) : 132-140.

Gomez, K. A. and Gomez, A. A. 1984.Statistical Procedures for Agricultural Research, 2nd edition. John Wiley and Sons. New York, 680 pp.

Koltunov, V. A. 1984. Effect of different fertilizer rates and garlic productivity and storability. V'isn. Sil'skogospodars koi Nauki.11 pp 52-54.

Panchal, G. N. 1989. Response of garlic (Allium sativum L.) to irrigation scheduling based on IW/CPE ratio under varying levels of nitrogen and phosphorus, M.Sc. (Agri.) Thesis Gujarat Agricultural University, Sardarkrushinagar. 1(4): 232-234.

Pandey, U. B. and Singh, D.K. 1993. Response of garlic to different levels of irrigation and nitrogen. News Letter National Horticultural Research and Development Foundation. 13 (3/4): 1012.

Patel, M. N. 1993. Response of garlic (Allium sativum L.) to irrigation scheduling based on IW/CPE ratio under varying levels of spacing and nitrogen. Gujarat Ph.D. (Agri) Thesis (Unpublished) Gujarat Agricultural University, Junagadh.

Reddy, G. S., Suryanarayana, K., Reddy, K. M. and Reddy, K. C. 2000.Effect of different levels of nitrogen and phosphorus on yield and yield components in garlic (Allium sativum L.). J. Res. ANGRAU. 28 (3): 56-59.

Shanmugasundaram, S. 2004. Vegetables and surmountable challenges. The Hindu Survey of Indian Agriculture.

Thakur, B. S. 2011. Effect of planting date, nitrogen and phosphorus levels on 
marketable bulb yield in garlic (Allium sativum L.) under mid hill conditions of Himachal Pradesh. J. Hill Agril. 2(1): 42-46.

Yadav, P.K. 2003.Effect of nitrogen and potassium on growth and yield of garlic (Allium sativumL.) in western Rajasthan. Haryana J. Horti. Sci.
32(3/4): 290-291.

Yadav, R.S., Sammauria, R. and Rathore, M.S. 2007. Effect of nitrogen and potassium on the growth, yield and quality of garlic (Allium sativumL.) in light textured soils of Rajasthan. The Indian J. Agril. Sci. 77(3): 34-36.

\section{How to cite this article:}

Piyush Verma, L. R. Varma, Yogesh Pawar and Joshi, P. C. 2020. Effect of Different Levels of Nitrogen and Methods of Application on Growth and Yield of Garlic (Allium sativum L.). Int.J.Curr.Microbiol.App.Sci. 9(05): 1458-1466. doi: https://doi.org/10.20546/ijcmas.2020.905.166 